INTERNATIONAL JOURNAL OF MULTidisciplinARY RESEARCH AND ANALYSis

ISSN(print): 2643-9840, ISSN(online): 2643-9875

Volume 05 Issue 01 January 2022

DOI: 10.47191/ijmra/v5-i1-18, Impact Factor: 6.072

Page No.- $133-148$

\title{
Effects of Digital Banking on The Performance of Commercial Banks in Nigeria $2010-2019$
}

\author{
Chukwu, Kenechukwu Origin ${ }^{1}$, Molokwu, Samuel Rapuluchukwu ${ }^{2}$ \\ ${ }^{1}$ Department of Banking and Finance, Nnamdi Azikiwe University, Awka, Anambra State, Nigeria. \\ ${ }^{2}$ Access Bank Awka Branch, 222 Zik Avenue, Awka Anambra State.
}

\begin{abstract}
In this study, the effect of digital banking on the performance of Commercial Banks was examined from 2010 to 2019. The study applied the Autoregressive Distributive Lag (ARDL) framework to examine the relationship between point of sales machine (POSG), Banking Transactions made through unstructured supplementary service data (USSDG), Web banking (WEBG) and Return on Assets (ROA) of commercial banks in Nigeria. The data were obtained from the statistical bulletins of the Central Bank of Nigeria (CBN) and annual reports of Nigeria Deposit Insurance Corporation (NDIC). The result of the analysis revealed that digital banking has positive and insignificant effect on the performance of commercial banks in Nigeria. . In the light of this findings, the study recommends the need for relatively stable network: In other to reduce number of failed transactions, banks are hereby encouraged to liaise with network providers and their engineers to develop a standardized network platform exclusively for each of the digital banking channels. Also there is need for digital banking education to bank customers on the benefits of digital banking. Equally there is need for all banks to have 24 hours working cyber security department in order to ensure that the channels are not hijacked by cyber criminals.
\end{abstract}

KEYWORDS: Return on assets, point of sales machine and web banking.

\section{INTRODUCTION}

The Nigerian banking industry has undergone and still undergoing operational, legislative and technological changes (Oyewole \& El-maude, 2013). Aside from the legislative changes in mandatory minimum capital, liquidity levels and reserves, there has been a gross deviation from the normal day to day withdrawal, deposits and cash payments to a more digitized payment system. The business of banking which has been basically defined as the acceptance of deposits and granting of money has always been done within the halls of the bank. But today, deposit acceptance and granting of money loans are consummated outside the halls of the bank with the platforms provided by digital banking (Eze \& Egoro, 2016).

Digital banking is the broad range of banking services accessed and delivered through digital channels, like Mobile phones, Personal Computers, the Internet or Cards linked to a reliable digital payment system (Ukoh, 2019). Such services include Payments, Withdrawals, Deposits and Credits, Remittances and Funds transfers, Balance enquiry, Airtime Top-Ups and even credit transactions (Ukoh, 2019). Digital banking basically refers to the moving online of all the traditional banking activities and programs that historically were only available to customers when physically inside of a bank branch.

Today, bank customers can send money to their family, friends or customers from the comfort of their bed without time restrictions. Electricity bills payments and subscriptions to television channels can now be made without paying a physical visit to the bank or taking cash to the office of the energy distribution company or television station. The streets are now clustered with people authorized by banks to carry on agent banking on their behalf. Therefore obtaining cash for petty transactions is now at the doorstep of the people.

The sudden spike in digital payments did not end with POS banking, Mobile banking, ATM banking or Internet banking. It also pervades into unstructured supplementary service data (USSD) banking and quick response (QR) banking. The USSD banking made it possible for bank customers without internet enabled devices to make and receive payments with their phones with use of codes. The QR code banking makes it easy for smart phone users the make payments by merely scanning the QR code provided by the merchant from whom he/she wants to purchase from. Today, the unavailability of bank branch in any particular 


\section{Effects of Digital Banking on The Performance of Commercial Banks in Nigeria 2010 -2019}

location does not hinder banking services. These channels and many other upcoming digital channels has made banking seamless and without boundaries. The ever evolving digital channels have won the heart of the management of most financial institutions in Nigeria (Oyewole \& El-maude, 2013). This may be because of the comfort and convenience it provides for its customers.

The digital banking services are spearheading greater portion of the payment system globally and in Nigeria as well. In Nigeria today, digital banking services have diversified from basic money transfer and bill payments to credit, cross-border remittances, savings, bulk disbursements and other value-added services like pay-as-you-go utility bills, etc (Taiwo \& Agwu, 2017). On the other hand, banks as business organizations are expected to make some profits and grow the wealth of the shareholders. Profitability of a bank is the financial strength of the bank over a period of time on the basis of certain criteria like return on assets, returns on investments, earnings per share, etc. These measures are used to verify the extent to which resources of the bank are adequately utilized to create wealth for the shareholders.

In their bid to make profits, they are always faced with measures to maximize profits and minimize losses. This is also accompanied with the challenge of keeping up with the competition in the industry. Hence they adopt all measures within the regulatory purview to keep up with their day to day operations, remain competitive in the industry and at the end, make profits for the shareholders. In an attempt to make these profits, several processes and procedure are removed, reorganized or changed. These changes in modes of operation brought about the foundation of digital banking in Nigeria (Ukoh, 2019).

The digital banking in Nigeria however has been accompanied by enormous challenges ranging from regulatory challenges to digital theft and robbery (Taiwo \& Agwu, 2017). The platform provided by the digital banking has created room for identity theft, unauthorized access to someone's funds, forgeries and difficulty in apprehending the digital thief/arm robber. In an attempt to curb these identified problems, the Central Bank of Nigeria has come up with policies that are consciously aimed at regulating the use or the extent of the use of these platforms provided by digital banking. Some of these policies include specifying the amount of transactions that a customer of a bank can carry on using any of these platforms per day/week, ensuring appropriate approvals are obtained before using any of these platforms and ensuring that adequate security gadgets are provided in areas where these platforms are used. All these policies/measures also have costs implication on the banks which ultimately has an effect on the profitability.

Various research work Okiro and Ndungu (2013), Malhotra and Singh (2009), Agu Onay (2008) Oyewole et al (2013), David-West et al (2018), Monyoncho (2015) and Abaenewe et al (2013) etc has been carried out on this subject matter and results show that digital has significant effect on performance of commercial banks while other results show insignificant effect. Their findings are contradictory and it is on this background that the study was motivated to fill the knowledge gap on the effects of digital banking on the performance of commercial banks in Nigeria from 2010 -2019. The paper is arranged as follows. Section two focuses on literature review, section three focuses on theoretical framework, section four on methodology, section five on results and discussion, section six on conclusion and policy implication.

\section{LITERATURE REVIEW}

The word digital means "expressed as series of digits or numbers 0, 1 - 9" (Scott \& Davis, 2015). Certain authors have viewed digital banking as e-banking, internet banking etc. There has not been a generally accepted definition of digital banking owing to the evolving dynamic and sophisticated technological platform on which it operates. E-banking, digital banking and electronic banking all involve manipulation or transfer of money in the form of digits, they however differ on the platforms providing such services (Taiwo \& Agwu, 2017). While internet banking platforms basically involves connection to internet before movement of digits, digital banking in addition to the e-banking also encompass all other methods of movement of digits for banking transactions such as the unstructured supplementary service data (USSD).

Oyewole, Abba, Gambo and Abam (2013) termed e-banking as automated delivery of new and conventional banking products and services directly to customers through electronic, interactive channels. Some of the channels through which digital banking services are consummated include Automated Teller Machines (ATMs), Point of Sales (POS), Unstructured Supplementary Service Data (USSD), Mobile apps, web portals etc.

IBM Global Services (2015) notes that digital banking is a set of alternative delivery channels for banking services. It has to do with conducting financial transactions through various electronic means, without physically interacting with the bank. Digital banking can be said to be alternative options for processing banking transactions other than the normal traditional means (Chebii, 2013). Digital banking may include branchless banking, implying availability of distribution channel strategy used for delivering financial services without relying on bank branches. While the strategy may complement an existing bank branch 


\section{Effects of Digital Banking on The Performance of Commercial Banks in Nigeria 2010 -2019}

network for giving customers a broader range of channels through which they can access financial services, branchless banking can also be used as a separate channel strategy that entirely forgoes bank branches. Digital banking may include e-banking, electronic banking, online banking, virtual banking, direct banking and high tech-banking.

The advancement in communication and computer technology have made it possible that one can do most banking transactions from any location even without stepping into a physical financial structure through digital banking channels. In an effort to reach the unbanked people and financial institutions outreach on alternative banking channels, a revolution in the range of payment solutions has been witnessed. Digital banking channels used includes all modern means of banking such as ATM, internet banking, bank automation, core banking, credit cards, debit cards, mobile banking (Ukoh , 2019). Chebii (2013) notes that digital banking adopts alternative channels which have highly been in use include Mobile banking, POS Banking and Internet Banking. Ogilvie (2008) argues that alternative banking channels are the newer methods of carrying on banking operations. Some of these digital banking channels are discussed below;

\subsection{Point Of Sales (POS) Banking}

The word "POS" is an acronym for point of sale. POS is a commercial term used to refer to a place in a shop where a product is passed from seller to the customer. POS banking refers to a method whereby people can access banking services via card terminals. POS banking, also known as agent banking involves the transfer of funds, withdrawal of funds, sales of recharge cards and bill payments such as Gotv, DSTV and electricity bills (Chebii, 2013). The business is an extension of services offered by financial institutions like banks through which customers get convenience. Therefore the fee charged on customers for this services is sometimes called convenience fee. The use of agents diminishes transaction costs as well as addressing the lack of inducements or capacity to institute formal branches in definite areas (Ndungu, 2015). Regulation allowing agent banking enables for sufficient business enticements for both agents and financial institutions to amplify outreach by delivering financial services via a network of agents (Melzer, 2006). The use of agents offer the possibility of massive outreach to people in locations that remain underserved, especially those in hard to reach rural areas. Ivatury and Lyman (2006) noted that agency banking has enable bank customers to access the basic banking services, for example, cash deposit and cash withdrawal conveniently or what would be termed as within the comfort of their neighborhood. The convenience of access to banking services and the extended hours that the agencies work has been the most attractive features to the customers.

\subsection{Unstructured Supplementary Service Data (USSD) Banking}

The unstructured supplementary service data (USSD) is currently one of the leading technological innovations that deliver mobile financial services to both low and high-income customers (Ukoh , 2019). The USSD banking makes use of specific code for each bank operating in the financial system. The bank code is a convenient, fast, secure, and affordable way to access your bank account 24 hours a day, 7 days a week through your mobile phone without internet data (NIBSS, 2018). They are codes that ease the stress associated with banking in Nigeria, making it more efficient and giving the customers complete access to their accounts. USSD banking occurs where customer of any bank dials the USSD code and completes a banking command. It sounds interesting that queuing up in the bank, trying to complete accounts recharge or making transfers has been taken away with this USSD code mobile banking service. It makes everything easy, and seamless (Taiwo \& Agwu, 2017). The USSD code is for every bank, and everyone that owns accounts for each bank. That means, if you are using First bank, you are fully entitled to use their transfer code for easy mobile banking (NIBSS, 2018). Whether you are saving account holder, current account holder, you are completely authorized to use your prospective bank codes and it is easy to use. The below list contains USSD code for some banks in Nigeria.

\subsection{Web Banking}

Web banking, also known as internet banking, is an electronic payment system that enables customers of a bank or other financial institution to conduct a range of financial transactions through the financial institution's website (Ginn, 2011). Internet banking software provides personal and corporate banking services offering features such as viewing account balances, obtaining statements, checking recent transaction and making payments. In recent time, many banks began to view web-based banking as a strategic imperative. As at 2008 almost all the Nigerian banks have fully developed websites and web portals for online banking (Taiwo \& Agwu 2017). This type of banking has also advanced into the use of mobile banking applications. The attraction of banks to online banking are fairly obvious: diminished transaction costs, easier integration of services, interactive marketing capabilities, and other benefits that boost customer lists and profit margins (Abaenewe, et al. 2013). Additionally, online banking services allow institutions to bundle more services into single packages, thereby luring customers and minimizing overhead. 


\section{Effects of Digital Banking on The Performance of Commercial Banks in Nigeria 2010 -2019}

To access a financial institution's online banking facility, a customer with internet access will need to register with the institution for the service, and set up a password and other credentials for customer verification (NIBSS, 2018). The credentials for online banking is normally not the same as for telephone or mobile banking. Financial institutions now routinely allocate customers numbers, whether or not customers have indicated an intention to access their online banking facility. Customer numbers are normally not the same as account numbers, because a number of customer accounts can be linked to the one customer number. Technically, the customer number can be linked to any account with the financial institution that the customer controls, though the financial institution may limit the range of accounts that may be accessed to, say, cheque, savings, loan, credit card and similar accounts.

\subsection{Digital Banking Enablers \\ Token}

This is additional security instrument usually attached to an account for the purpose of providing additional authentication before a transaction is concluded. This instrument is usually used by people using web banking applications or mobile app. This support device can be in hardware or software.

\section{Quick Response Codes (QR Codes)}

While they may look simple, QR codes are capable of storing lots of data (Ukoh, 2019). When scanned, the QR code allows the user to access information instantly. QR code payment is a contactless payment method where payment is performed by scanning a QR code from a mobile app (Ogutu \& Fatoki, 2019). This is an alternative to doing web, POS or USSD banking at point of making a purchase or sale of goods or services. This avoids a lot of the infrastructure traditionally associated with electronic payments such as payment cards, payment networks, payment terminal and merchant accounts. To use a QR code payment the consumers scans the QR code displayed by the merchant with their phones to pay for their goods. They enter the amount they have to pay and finally submit.

\subsection{Financial performance}

Ndungu (2015) explained that Performance is the degree to which an achievement is being or has been accomplished. It is the act of performing; execution, accomplishment, fulfillment, etc. It is the accomplishment of a given task measured against preset standards of accuracy, completeness, cost, and speed.

The firm's success, conditions, and compliance is measures through performance. On the other hand, financial performance is a measure of the change of the financial state of an organization, or the financial outcomes that results from management decisions and the execution of those decisions by members of the organization (Greenwood \& Jovanovic, 1990). Financial performance is conceptualized as the extent to which a firm increases sales, profits, and return on equity. Financial performance is essential to the survival of firms in the competitive and uncertain environment (Sousa \& Voss, 2006). The success of an organization is gauged highly on financial performance hence, performance has been highly measured using financial measures. Financial performance ultimately reflects whether or not service quality is realized in a firm.

Galor and Zeira (2000) proposed four possible types of measurement for organizational performance name1y: outcomes (turnover, absenteeism, job satisfaction); organizational outcomes (productivity, quality, service); financial accounting outcomes (return on assets, profitability) and capital market outcomes (stock price, growth, returns). However, scholars have proposed a broader performance construct of business performance to incorporate non-financial measures including market share, customer satisfaction and new products. Measures recommended for financial analysis that determine a firm's financial performance are grouped into five broad categories: profitability, liquidity, solvency, repayment capacity and financial efficiency (Crane, 2010). The components of CAMELS - an acronym for Capital Adequacy, Asset Quality, Management Quality, Earnings Potential, Liquidity, and Sensitivity to Market Risk have traditionally been the yard stick for an assessment of banks' performance. Since CAMELS combines the financial soundness (credit risk) and market (market risk) indicators, it is used by banking sector supervisory authorities (King, Nuxoll, \& Yeager, 2006) and rating agencies (Rawcliffe, Peach, \& Shaw, 2008) to assess soundness of banks.

\section{THEORETICAL FRAMEWORK}

\subsection{The Technology acceptance theory (TAT)}

Technology acceptance theory was first proposed by Davis, Bagozzi and Warshaw (1989) to examine the conceptual model of the intention of user or the degree to which information system or new technology has been done. TAT is designed on the basis of perceived usefulness and ease of use of the new technology. Perceived usefulness of technology suggests the personal conviction to better the degree of work performed by a specific new technology or information system. Perceived ease of use of 


\section{Effects of Digital Banking on The Performance of Commercial Banks in Nigeria 2010 -2019}

new technology implies how easy a person can learn the way to use or run a new technology or information system (Scott \& Davis, 2015). The TAT has stressed on the way perceived ease of use of new technology directly influences perceived usefulness of the technology. External variables such as environment factors surrounding an individual intervene in influencing perceived ease of use and usefulness. Hence, Technology Acceptance Theory has a basis in both crucial perceptive factors that is perceived usefulness and perceived ease of use. Technology Acceptance Theory is applied vastly on the researches involving information technology. Liu and Arnett (2000) analyzed the important variables to come up with a successful website which has its basis on TAT. The TAT is relevant to this study in that it looks into how easy a person can learn the way to use or run a new technology or information system. As stated in the problems of this study, one of the earliest fear that were expressed by people on digital banking is that the technology is new to the environment and that not everyone knows how to use it. It therefore follows that a new technology will likely pass the general acceptability test if it is perceived useful to the people and also easy to use.

\subsection{Agency Theory}

Agency Theory was developed primarily by Jensen and Meckling (1976). Agency theory analyzes the relationships between a business and its agents. The key issues in agency theory center upon whether adequate market mechanisms exist for agents to act in ways that maximize the utility of a firms where ownership and control are separated. Under the terms of agency theory, a principal (P) passes on authority to an agent (A) to conduct transactions and make decisions on behalf of the principal in an effort to maximize P's utility preferences.

Agency problems can arise if: $\mathrm{P}$ and $\mathrm{A}$ have different goals; $\mathrm{P}$ and $\mathrm{A}$ have disparate skills in evaluating $\mathrm{A}$ 's performance; $\mathrm{P}$ and $\mathrm{A}$ possess different sets of information relevant to the managerial decisions $\mathrm{A}$ must make as a representative of $\mathrm{P}$; or $\mathrm{P}$ and $\mathrm{A}$ have different degrees of risk aversion. At the core of agency problems is the fact that principals may not be able to monitor agents, either perfectly or costless, as to the agent's actions or the information behind those actions. In the commercial banking industry, ownership is becoming increasingly diversified among individual and institutional shareholders, and the dominance of individual stockholders in the industry appears, on the whole, to be decreasing. These trends may exacerbate "agency problems" in the banking industry if these problems truly exist. Agent banks are retail establishments contracted by the banks and authorized by the central banks to render services for banks. This theory points out the possibility of emergence of problems if the coordination between the banks and digital banking agent is not well managed. Some of such problems may arise where agents may increase transaction costs in order to make more profits however against the principals objective of providing low transaction cost in order to increase and retain its' customer base.

\subsection{Unified Theory of Acceptance and Use of Technology (UTAUT)}

UTAUT was first proposed and theorised by Venkatesh (2003). Several researchers including Venkatesh (2003) reviewed eight models regarding the usage of ICT, they are; the social cognitive theory and model, Diffusion of Innovations (DOI), Technology Acceptance Model (TAM), the model of PC utilization, the motivational model, Theory of Reasoned Actions (TRA) and Theory of Planned Behaviour (TPB). UTAUT was created mainly to help researchers in the field of IT/IS in the process of adoption and diffusion. In the theory, it is argued that there are 4 major: "Effort expectancy, performance expectancy, facilitating conditions and social influence". The four constructs have positive effect on IS/IT behavior intents and ultimately behaviour (Venkatesh, 2003).

UTAUT also provides a foundation for the current study. It discusses in details on how innovative technologies in banking sector is adopted and used by the employees of the bank as well as the clients of the bank. The model sought to discuss the intension of the user to adopt ICT and the succeeding behaviour of user. UTAUT offers the managers with decision-making tools that they can adopt to comprehend the introduction of new technology for prediction and elaboration of the behaviour of users in accepting IT.

Finally, this study is anchored on Technology Acceptance Theory. This is because, the TAT is a key theory that underpins the current study on how digital banking affects the commercial banks profitability in Nigeria as it looks into the perceived usefulness and ease of use of a new technology. The idea is that for banks to drive profitability through digital banking, it must be accepted by the people and to be acceptable to the people, it should be perceived useful and also very easy to use.

\subsection{Empirical Review}

Okiro and Ndungu (2013) investigated the impact of mobile banking and internet banking on financial performance of financial institutions in Kenya. The study also sought to identify the extent of use of mobile and internet banking in financial institutions. The population of interest in the study consisted of 61 financial institutions operating in Kenya. Sample survey with the use of questionnaire was adopted to obtain relevant data. The study was analyzed using T-test of the SPSS version 20.0. The result revealed that among the financial institutions surveyed, commercial banks had the highest usage of internet and mobile 


\section{Effects of Digital Banking on The Performance of Commercial Banks in Nigeria 2010 -2019}

banking; SACCOs had the second highest usage whereas none of the microfinance institutions used internet banking. The study found out that mobile banking faces various challenges which include system delays by the mobile money transfer service providers, slow processing of transactions especially during the weekends, high transactions costs, limit on the amount of money that can be withdrawn in a day and fraud. They concluded that mobile banking and internet banking has contributed to the financial performance of financial institutions in Kenya although efforts should be made to tackle the challenges raised.

Malhotra and Singh (2009) studied the impact of internet banking on bank performance and risk in India. The study was done on 85 commercial banks over the period 1998-2006 which represented nearly 39 percent of total scheduled commercial banks in India. Using information drawn from the survey of 85 scheduled commercial bank's websites, the results showed that nearly 57 percent of the Indian commercial banks are providing transactional Internet banking services. The univariate analysis indicated that internet banks are larger banks and have better operating efficiency ratios and profitability as compared to non-Internet banks. Internet banks rely more heavily on core deposits for funding than non-Internet banks do. However, the multiple regression results reveal that the profitability and offering of internet banking does not have any significant association, on the other hand, internet banking has a significant and negative association with risk profile of the banks. Since the study was based on only internet banking it's important to extend the study to cover to cover other forms of electronic banking.

Onay (2008) studied the impact of internet-banking on banks profitability in Turkey. The analysis covered 13 banks that had adopted online banking in Turkey between 1996 and 2005. By using bank specific and macroeconomic control variables, they investigated the impact of internet banking on the return on assets(ROA) and equity(ROE), the interest spread, overhead expenses, commission and fee income controlling for systemic bank crises in the country during the timeframe. The study included time-lagged measures of internet banking adoption to exhibit the changes in effect over time. The results showed that internet banking starts contributing to banks' ROE with a time lag of two years confirming the findings of while a negative impact is observed for one year lagged dummy. The results provided some evidence that investment in e-banking is a gradual process.

Oyewole et al. (2013) examined E-banking and Bank Performance in Nigeria. The study covers all the banks in Nigeria and data obtained covered 2008 to 2012. Variables used in their study include Return on Asset (ROA), return on equity (ROE) and net interest margin. Ordinary Least Squares model was used to analyse the data obtained. The result of their study showed that ebanking begins to contribute positively to bank performance in terms of ROA and NIM with a time lag of two years while a negative impact was observed in the first year of adoption.

In another study, David-West et al (2018) made a state of the market report on digital financial services in Nigeria. They used survey design to examine the Percentage of banked and under banked male, Percentage of banked and under banked female. They concluded that financial inclusion is a stimulant for economic development. They also observed that Nigeria recorded progress in growing the banked and under-banked segments, but a significant number lack access to formal financial services and are yet to be categorized as banked. Another observation is that digital banking services awareness and utilization is low and non-existent among target segments under-banked and unbanked.

Monyoncho (2015) appraised relationship between banking technologies and financial performance of commercial banks in Kenya. The variables used in the study include ATMs, Mobile, Internet, Debit and Credit cards transactions. The data obtained were analyzed using SPSS version 21 Pearson moment correlation. The result of the analyses showed that ATM innovations offer financial institutions the opportunity to transform the ATM from a cash dispenser to a customer relationship management tool, helping to enhance loyalty among all customers. They also observed that credit cards are being adopted by the banks so as to increase income, and to reduce credit and liquidity risks while mobile banking was found to have major impacts on the profitability of commercial banks.

Abaenewe et al (2013) did a study on electronic banking and bank performance in Nigeria. Their study covered the period of 2007 to 2012. The variables in their study include Electronic naming transactions, Returns on equity (ROE) and returns on assets (ROA). Standard statistical technique and ordinary least square regression of E-views were used as analytical tool. Their study revealed that the adoption of electronic banking has positively and significantly improved the returns on equity (ROE) of Nigerian banks. On the other hand and on the contrary, it also revealed that e-banking has not significantly improved the returns on assets (ROA) of Nigerian banks.

Ogutu and Fatoki (2019) examined effect of e-banking on financial performance of listed commercial banks in Kenya. Their variables for the study include Mobile banking, agency banking, ATM banking and online banking. The ordinary least square regression technique was used. Their results showed that there was strong positive relationship between mobile banking, agency banking, ATM banking and online banking and financial performance of listed commercial banks in Kenya. They further 


\section{Effects of Digital Banking on The Performance of Commercial Banks in Nigeria 2010 -2019}

observed that financial performance of commercial banks and $\mathrm{m}$-banking were strongly and positively correlated. They also recorded a strong positive correlation between financials performance of individual commercial bank and agency banking.

In a similar study, Eze and Egoro (2016) examined electronic banking and profitability of commercial banks in Nigeria using frequency tables and charts. Their study covered 2010 -2015. The variables for their study are estimated transactions on ATM, POS and profit before interest and taxes. The data obtained were analyzed using tables, chats and ordinary least square regression (V.20). From the result of their study, they concluded that the impact of electronic banking on the profitability of commercial banks was significant; whereas, the impact of the individual channels was varied.

Juddy (2013) examined the effect of digital banking on financial performance of commercial banks in Kenya. Their study covered 2007 to 2012. The study was carried out using sample survey. Credit cards, Debit cards and ATMS Transactions were used as proxy for digital banking. The result showed that Fees and commission from debit cards, credit cards and mobile banking has a significant effect on returns on asset whereas fees and commission from internet banking as well as the amount of money that commercial banks invest in electronic banking to install, training staff and maintain the platforms has no or minimal effect on return on assets. He concluded that the adoption of digital banking has enhanced performance of commercial banks due to increased efficiency, effectiveness and productivity.

Taiwo and Agwu, (2017) explored the role of e-banking on operational efficiency of banks in Nigeria. Pearson correlation was used to analyse the results obtained using the Statistical Package for Social Sciences (SPSS). The variables used for the study include profit before interest and taxes, mobile application and ATM transactions. The study showed that Banks' operational efficiency in Nigeria since the adoption of electronic banking has improved compared to the era of traditional banking. This improvement was noticed in the strength of banks, revenue and capital bases, as well as in customers' loyalty.

Ndungu (2015) studied the effect of alternative banking channels on financial performance of commercial banks. Operating expenses, agency banking, mobile banking and customer deposits based were used as variables for the study. The study established that $73.4 \%$ of the variation in financial performance of commercial banks in Kenya was explained jointly by operating expenses, agency banking, mobile banking and Customer deposits. That agency banking, mobile banking, customer deposits and operating expenses were positively related to financial performance of commercial banks.

Kairiza, Kiprono, and Magadzire (2017) studied the effectiveness of electronic banking in ensuring efficiency of services in commercial banks using data from listed commercial and merchant banks in Zimbabwe. The study covered the period 2010 to 2016. The Automated teller machines, and POS banking were used as variables for the study. The data obtained were analysed using ordinary least square regression. They found out that eletronic banking channels has helped in improving quality of services in commercial banks. However, they also found out that POS banking has not contributed positively to efficiency of banks in Zimbabwe for the period studied.

Kongiri (2012) studied the effects of cashless banking on digital banking in Kenyan commercial banks. The study covered the period of 2007 to 2011.Internet banking and ATM banking were used as variables for the study. The study adopted a panel data design and descriptive research design to meet its objectives. Annual financial statements of 37 Kenyan commercial banks from financial years 2007 to 2011 were obtained from the Central Bank of Kenya (CBK). The data made up of a sample of 185 study units was analyzed using multiple linear regression method. Findings led to the conclusion that cashless banking has grossly increased Internet banking, ATM banking.

Rosen (2013) investigated effect of the use of mobile banking and agent banking in the banking system in Kenya. Their study covered the period of 2007 - 2012. Their mobile banking and agent banking data were obtained and analyzed using OLS. Potential financial gains were identified and these gains were later explored on an individual bank survey. The survey examined the effects from these non-conventional channels on banks based on their level of operation, customer base and profitability. Findings from this study suggest that mobile banking and agent banking have facilitated the delivery of financial services to the population in Kenya that was previously excluded and the result is an efficient, responsive and profitable banking system.

Yorulmaz (2018), made an analysis of the construction of global digital banking indices. His study aims to measure the extent of financial access by constructing a broader multidimensional digital banking indices which contain aggregate information of the extent of the digital banking channels. The study covered the period of 2003 to 2015 . The variables used in the study are geographic ATM penetration, geographic branch penetration, deposit accounts per capita, and fees of ATM cards. The study showed and increasing periodic index of the selected variables. The results also showed that adding new indicators of digital banking into the index construction process does not have any detrimental effect on the index.

Isibor et al (2018) examined the impact of electronic banking technology on customers' satisfaction and economic growth in Nigeria. The researcher went to four banks in Sango Ota in Ogun state: Zenith Bank, Guaranty Trust Bank, Access Bank plc, and UBA plc and then distributed 120 questionnaires to various customers within the-banking premises. The Pair Sample t-test statistical parametric analysis was employed to test the significance through the use of SPSS statistical package. The researcher's 


\section{Effects of Digital Banking on The Performance of Commercial Banks in Nigeria 2010 -2019}

intention was to establish the level of significance of electronic banking and customers' satisfaction on the one hand and electronic banking and profitability of banks on the other hand. It was observed that the average people prefer electronic banking to manual banking. They also concluded that electronic banking has improved banks' profitability.

Olaiya, and Adeleke (2019) investigated electronic banking and profitability of deposit money banks in Nigeria between 2010 and 2018. The study relied on the secondary source of data collection. Data for the study were obtained from Central Bank of Nigeria's (CBN) Statistical Bulletin and CBN Financial Stability Reports. Data were analyzed by conducting unit root test and cointegration bound test. Estimation was done by employing Autoregressive Distributed Lags using E-view 9.0 version. In the specified model for this study, four variables, namely, automatic teller machine transaction value (ATMTV), point of sale transaction value (POSTV), mobile banking transaction value (MBTV) and internet banking transaction value (IBTV) while commercial banks performance was proxied by returns on assets (ROA). The study revealed that two independent variables namely ATMTV and POSTV individually have positive relationship ROA, while both MBTV and IBTV defied apriori expectations as they individually have negative relationship with ROA. However, a combined test for all the four variables revealed a no significant relationship with ROA. The study therefore, concludes that digital banking channels have no significant effect on the performance of banks in Nigeria in the short run for the period covered by the study.

Auwal, Shafiu and Haslinda. (2015) appraised the impact of online banking on the performance of Nigerian banking sector.Their study covered the period of 2000 to 2014. They measured E-banking by the expenditure made on information and communication technology (ICT) investments, number of debit cards issued to customers, and number of automated teller machines (ATMs) installed by the banks. Return on assets (ROA), return on equity (ROE), and net interest margin (NIM) was used as performance variables. The impact of e-banking on the bank performance was examined in two periods: pre-consolidation (i.e., before adopting the e-banking) and post-consolidation (i.e., after adopting the e-banking). Secondary data was gathered from annual reports of 21 Nigerian banks. The SPSS software was used for data analysis. It was argued that majority of the business sectors, including banks, have taken advantage of using IT to enhance their business operations. They concluded that online banking has significant positive effect on the profitability of banks.

Ibrahim and Daniel (2019) looked into the impact of E-banking on the development of banking sector in Nigeria. Their study covers a mortgage bank in Wuse, Abuja, namely Infinity Trust Mortgage bank. Questionnaire was used as research instrument for the study. From a total of ninety two (92) copies of the questionnaire distributed to the respondents, eighty (80) copies representing $87 \%$ were duly completed and returned while (12) copies representing $13 \%$ were not returned. The questionnaires were analyzed using SPSS analytical tool. From their analyses, they discovered that electronic banking has both negative and positive impact in the Nigerian banking sector. While it has greatly improved service delivery on the positive angle but on the negative side, it is prone to electronic fraud and unauthorized access to information.

\section{METHODOLOGY}

This study on effects of digital banking on performance of commercial banks in Nigeria made use of expost-facto research design. This is because data used in the study were results of the events that happened in the past. The data include the growth rate of the volume and value of POS, USSD and Web banking transactions from 2010 - 2019. Autoregressive Distributed Lag was used in the study in order to examine the effects of digital banking on the performance of commercial banks in Nigeria. In order to achieve the objective of the study, the model of Oyewole and El-maude (2013) was adopted and modified. Their model is stated thus:

$R O A=f\left(M B_{t r}+N I P t r+I N T_{t r}\right)$

However this model was modified to suit the current study hence the function;

$$
R O A=f\left(P^{\prime} S_{b}+U S S D_{b}+W E B_{b}\right)
$$

The econometric function then becomes;

$$
R O A=\beta_{0}+\beta_{1} \text { POS }_{b}+\beta_{2} \text { USSD }_{b}+\beta_{3} W_{E B}+\mu
$$

The model above specifies the econometric relationship between the dependent variables ROA, and the independent variables POS, USSD, WEB. These digital variables were selected based on their perceived effect on bank profitability by the researcher.

Where;

ROA = Return on Assets

$\mathrm{POSG}_{b}=$ Banking transactions made through Point of sales machine

$\mathrm{USSD}_{\mathrm{b}}=$ Banking Transactions made through unstructured supplementary service data

$\mathrm{WEB}_{\mathrm{b}}=$ Web banking 


\section{Effects of Digital Banking on The Performance of Commercial Banks in Nigeria 2010 -2019}

$\beta_{0}=$ Constant

$\beta_{1}, \beta_{2}, \beta_{3}=$ Estimation Parameters

$\mu=$ Error Term.

\section{Definition of Variables}

Dependent Variable: (ROA) Return on assets is an indicator of how profitable a company is relative to its total assets. ROA gives a manager, investor or analyst an idea as to how efficient a company's management is using its assets to generate earnings. It is an indicator of how profitable a company is relative to its total assets.

Independent Variables: (POS Banking) POS refers to "Point of Sale", a machine which banks issue to their merchant customers to enable them sale or make purchases through the use of cards.

USSD Banking: USSD refers to "quick codes" or "feature codes" used as a communication protocol by GSM cellular telephones to communicate with the mobile network operator's computer or bank. All commercial banks in Nigeria have USSD codes which enable customers of banks to make transactions of various sorts.

Web banking: This refers to transactions carried out on the internet; either through the web of the bank or through the bank's mobile application.

The first step in this analysis is to describe the variables used in the study before we proceed to carry out stationarity test. Stationarity test was conducted using ADF test and PP test. The result of the ADF and PP test is shown in Table 2 to 5.

\section{RESULTS AND DISCUSSION}

The characteristics of the data series used in the analysis are presented in Table 1 . The table shows the summary of descriptive statistics used in the analysis. The mean value was shown to be 1.081000 for ROA, 89.16110 for POSG, 105.2718 for USSDG and 53.08971 for WEBG. The median value was shown to be 2.475000 for ROA, 69.12500 for POSG, 68.61704 for USSDG and 47.20925 for WEBG. The maximum and minimum of the series are 3.910000 and -9.280000 for ROA, 235.3800 and 34.44000 for POSG, 353.1895 and 10.87690 for USSDG, 137.9640 and -47.03900 for WEBG. The series standard deviations are 3.870692 for ROA, 59.82092 for POSG, 101.3594 for USSDG, 52.91478 for WEBG.

\section{Table 1. Descriptive Statistics}

\begin{tabular}{|l|l|l|l|l|}
\hline & ROA & POSG & USSDG & WEBG \\
\hline Mean & 1.081000 & 89.16110 & 105.2718 & 53.08971 \\
\hline Median & 2.475000 & 69.12500 & 68.61704 & 47.20925 \\
\hline Maximum & 3.910000 & 235.3800 & 353.1895 & 137.9640 \\
\hline Minimum & -9.280000 & 34.44000 & 10.87690 & -47.03900 \\
\hline Std. Dev. & 3.870692 & 59.82092 & 101.3594 & 52.91478 \\
\hline Skewness & -2.140185 & 1.616503 & 1.587417 & -0.102982 \\
\hline Sum Sq. Dev. & 134.8403 & 32206.88 & 92463.59 & 25199.77 \\
\hline Observations & 10 & 10 & 10 & 10 \\
\hline
\end{tabular}

Source: Author's Computation

The variables for the analysis were subjected to two types of unit roots test to determine whether there are unit roots or stationary series. In conducting this test, the Phillips-Perron (PP) and the Augmented Dickey-Fuller (ADF) unit root test with intercept would be employed to determine the stationarity of data. The unit root text from table 2 to table 5 shows that the variables are stationary at first difference which allow for ascertaining the cointegration relationship.

Table 2. Result of ADF Unit Root Test at level

\begin{tabular}{|c|c|c|c|c|}
\hline Variables & ADF Test Statistic & Test Critical Value at $1 \%$ & Test Critical Value at 5\% & Remark \\
\hline ROA & $-10.68529(0.0000)^{* *}$ & -4.420595 & -3.259808 & Stationary \\
\hline POSG & $-2.937079 \quad(0.0789)^{* *}$ & -4.420595 & -3.259808 & Not Stationary \\
\hline USSDG & $\begin{array}{ll}-2.473889 & (0.1509)^{* *}\end{array}$ & -4.420595 & -3.259808 & Not Stationary \\
\hline WEBG & $-4.382766(0.0105)^{* *}$ & -4.420595 & -3.259808 & Stationary \\
\hline
\end{tabular}

Source: Author's Computation 
Effects of Digital Banking on The Performance of Commercial Banks in Nigeria 2010 -2019

Table 3. Result of ADF Unit Root Test at $1^{\text {ST }}$ Diff

\begin{tabular}{|l|l|l|l|l|}
\hline Variables & ADF Test Statistic & Test Critical Value at 1\% & Test Critical Value at 5\% & Remark \\
\hline ROA & -12.58734 & -4.582648 & -3.320969 & Stationary \\
\hline POSG & -4.995416 & -4.582648 & -3.320969 & Stationary \\
\hline USSDG & -4.421883 & -4.582648 & -3.320969 & Stationary \\
\hline WEBG & $-5.994405(0.0021)^{* *}$ & -4.582648 & -3.320969 & Stationary \\
\hline
\end{tabular}

Source: Author's Computation

The Augmented Dickey-Fuller (ADF) unit root test indicates that the variables were stationary at level and first difference hence the need to confirm the unit root test. In order to achieve that Phillips-Perron (PP) unit root text was conducted and the result shown in table 3 and 4.

Table 4. Result of PP Unit Root Test at level

\begin{tabular}{|c|c|c|c|c|}
\hline Variables & ADF Test Statistic & Test Critical Value at & Test Critical Value at $\mathbf{5 \%}$ & Remark \\
\hline ROA & $-12.55821(0.0000) * *$ & -4.420595 & -3.259808 & Stationary \\
\hline POSG & $-2.936985 \quad(0.0789) * *$ & -4.420595 & -3.259808 & Not Stationarv \\
\hline USSDG & $-2.482557(0.1492)^{* *}$ & -4.420595 & -3.259808 & Not Stationary \\
\hline WEBG & $-4.382766(0.0105)^{* *}$ & -4.420595 & -3.259808 & Stationary \\
\hline
\end{tabular}

Source: Author's Computation

Table 5. Result of ADF Unit Root Test at $1^{\text {ST }}$ Diff

\begin{tabular}{|l|l|l|l|l|}
\hline Variables & ADF Test Statistic & Test Critical Value at & Test Critical Value at 5\% & Remark \\
\hline ROA & $-31.17599(0.0001)^{* *}$ & -4.582648 & -3.320969 & Stationary \\
\hline POSG & $-8.761169(0.0002)^{* *}$ & -4.582648 & -3.320969 & Stationary \\
\hline USSDG & $-7.429905(0.0005)^{* *}$ & -4.582648 & -3.320969 & Stationary \\
\hline WEBG & $-9.212776(0.0001)^{* *}$ & -4.582648 & -3.320969 & Stationary \\
\hline
\end{tabular}

Source: Author's Computation

\section{ARDL Co-integration Relationship}

The affirmation of the non-stationary of the data through the unit root test of ADF and PP permit for the determination of the co-integration relationship between the dependent and explanatory variables in the models. The ARDL was chosen as against the traditional Johansen co-integration because it is structured in such a way that it takes into account the different order of integration of financial time series data. Co-integration test For Long-run Effect

Pesaran and Shin (2001) showed that co-integrating systems can be estimated as ARDL models; it has the advantage to estimate co-integrating relationship on variables that are either I(0) or I(1). According to Pesaran et al. (2001), the asymptotic distribution of the F-statistic is non-standard regardless of whether the regressors are I(0) or I(1), and provide two adjusted critical values that establish lower and upper bounds of significance. The bound test follows the critical criterion at the lower bound and upper bound value for decision at the three levels of significance in $1 \%, 5 \%$ and $10 \%$.

Table 6. ARDL Bounds Tests for Co-integration

\begin{tabular}{|l|l|l|}
\hline Test Statistic & Value & $\mathrm{k}$ \\
\hline F-statistic & 248.2288 & 3 \\
\hline Critical Value Bounds \\
\hline Significance & $\mathrm{I}(0)$ Bound & $\mathrm{I}(1)$ Bound \\
\hline $10 \%$ & 2.37 & 3.2 \\
\hline $5 \%$ & 2.79 & 3.67 \\
\hline $2.5 \%$ & 3.15 & 4.08 \\
\hline $1 \%$ & 3.65 & 4.66 \\
\hline
\end{tabular}

Source : Author's Computation Using E-Views 10 Software 


\section{Effects of Digital Banking on The Performance of Commercial Banks in Nigeria 2010 -2019}

Given a computed F statistics Value of 248.2288 which is greater than the lower and upper critical bound values at $1 \%, 2.5 \%, 5 \%$ and $10 \%$ respectively, thus indicating the existence of a steady-state long-run relationship among the variables. This suggest that the various selected variables have a long run relationship with performance of commercial banks in Nigeria.

Decision rule: We reject null hypothesis of the co-integration relationship to accept the alternative that there is Co-integration. We thus, conclude that digital banking instrument as represented by POSG, USSDG and WEBG has a long-run effect on return on asset commercial bank in Nigeria.

\section{Nature of Long Run Relationship/ARDL Error Correction Model}

The ARDL result has proven that return on asset, Point of Sale, USSD Banking and Web banking are co-integrated/related in the long run. Consequently, the determination of the nature of the long run relationship becomes necessary as well as the speed of the adjustment to equilibrium.

Table 7. ARDL Co-integrating and Long Run Form for ROA $\rightarrow$ POSG+USSDG+WEBG

\begin{tabular}{|l|l|l|l|l|}
\hline \multicolumn{4}{|l|}{ ARDL Error Correction Regression } & \\
\hline Dependent Variable: D(ROA) & \\
\hline ECM Regression & Coefficient & Std. Error & t-Statistic & Prob. \\
\hline Variable & -1.084838 & 0.021774 & -49.82257 & 0.0000 \\
\hline CointEq(-1)* & 0.996520 & Mean dependent var & 1.343333 \\
\hline R-squared & 0.996520 & S.D. dependent var & 4.933541 \\
\hline Adjusted R-squared & 0.291055 & Akaike info criterion & 0.473829 \\
\hline S.E. of regression & \multicolumn{2}{|l|}{ Schwarz criterion } & 0.495743 \\
\hline Sum squared resid & 0.677703 & Hannan-Quinn criter. & 0.426539 \\
\hline Log likelihood & -1.132230 & & \\
\hline Durbin-Watson stat & 1.225551 & \multicolumn{5}{l}{} \\
\hline$*$ P-value incompatible with t-Bounds distribution. \\
Source: Author's Computation Using E-Views 10 Software
\end{tabular}

The speed of adjustment in Table 7 reveals that the model move toward equilibrium following disequilibrium in the explanatory variables. The ECM is significant and negatively signed with a coefficient of -1.084838 , a suggestion that $-108.4838 \%$ of error generated in previous period is corrected in current period.

\section{Diagnostic Test}

\section{Serial Correlation LM Test}

Table 8. Serial Correlation LM Test

\begin{tabular}{|l|l|l|l|}
\hline \multicolumn{3}{|l|}{ Breusch-Godfrey Serial Correlation LM Test: } & \\
\hline F-statistic & 0.230979 & Prob. F(2,2) & 0.8124 \\
\hline Obs*R-squared & 1.688743 & Prob. Chi-Square(2) & 0.4298 \\
\hline
\end{tabular}

Source: E-views 10.0 version data output

From table 8 , the $p$-value is greater than the chosen level of significance of $5 \%$, indicating the absence of autocorrelation in the models. The result of the serial correlation shows that the probability value is 0.8124 which is greater than 0.05 implying that we accept $\mathrm{H}_{0}$ and reject $\mathrm{H}_{1}$. We then conclude that there is no serial autocorrelation in the model and that the model is appropriate for the study.

\section{Normality Test}

The normality test was done using the Jarque-Bera Normality test, which requires that for a series to be normally distributed; the histogram should be bell-shaped and the Jarque-Bera statistics would not be significant. This implies that the $p$-value given at the bottom of the normality test table should be greater than the chosen level of significance to accept the Null hypothesis, that the series is normally distributed (Brooks, 2014). 


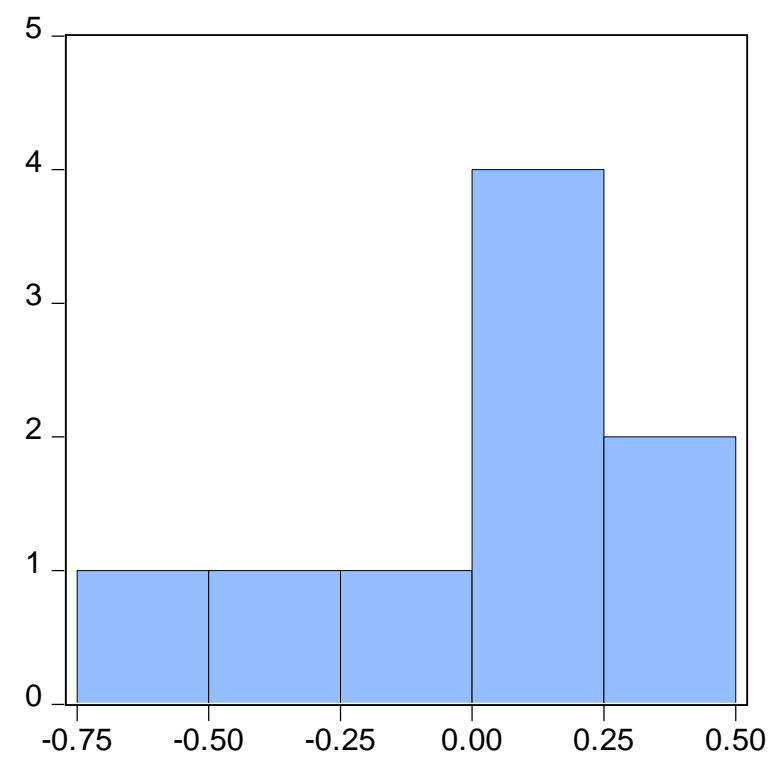

\section{Series: Residuals \\ Sample 20112019 \\ Observations 9}

Mean

8.02e-16

Median

0.111684

Maximum

0.327117

Minimum

$-0.553816$

Std. Dev. $\quad 0.291055$

Skewness $\quad-0.831274$

Kurtosis $\quad 2.460900$

Jarque-Bera 1.145511

Probability $\quad 0.563969$

Fig. 1. Normality Text

Source: E-views 10.0 version data output

The result of the normality test shows that the probability value of 0.563969 is greater than 0.05 . Based on this however we accept $\mathrm{H}_{0}$ and reject $\mathrm{H}_{1}$. We then conclude that the residuals are normally distributed and random.

\section{Ramsey Reset Test}

Table 9. Ramsey Reset Test

\begin{tabular}{|l|l|l|l|}
\hline & Value & Df & Probability \\
\hline t-statistic & 0.311761 & 3 & 0.7756 \\
\hline F-stati tic & 0.097195 & $(1,3)$ & 0.7756 \\
\hline
\end{tabular}

Source: Author's E-view 10 computations

The result of the Ramsey RESET test shows that the $p$-value of about $77.56 \%(0.7756)$ are greater than the critical value of 0.05..This shows that there is no apparent non- linearity in the regression equations and it would be concluded that the linear models are appropriate.

\section{CUSUM and CUSUM of squares tests of stability}

The stability test results are shown in figure 2 and 3. The CUSUM and CUSUM of squares are the tests used to check stability within the model. The results of stability test show evidence that the model is stable. This is indicated by a movement of blue lines located within the critical lines (two-red dotted lines) in the figures. Therefore, at $5 \%$ level of significance, the CUSUM and CUSUM of squares stability tests confirm good performance of the model.

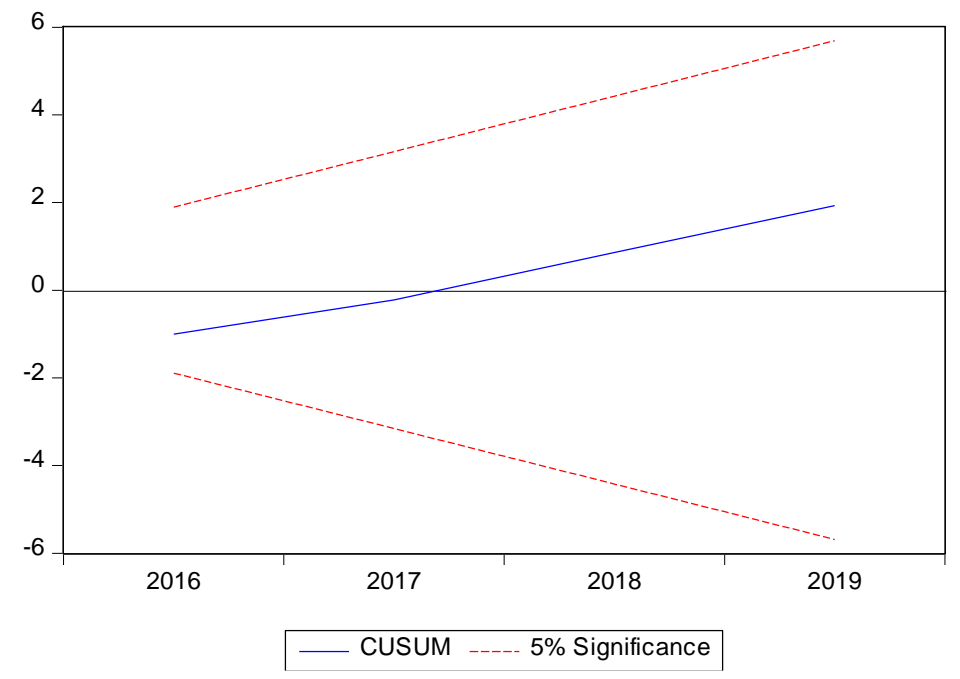

Fig. 2 CUSUM Text

Source: E-views 10.0 version data output 


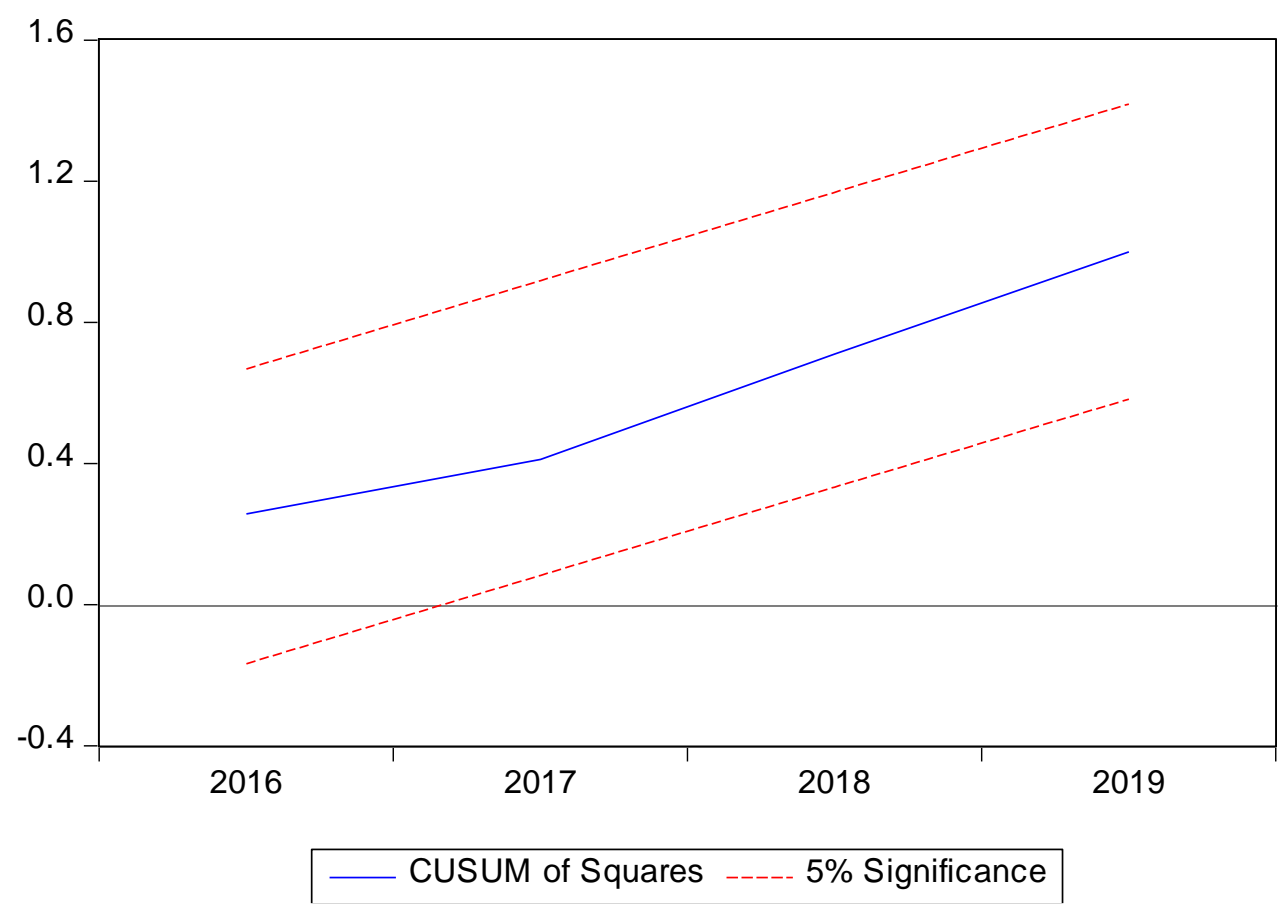

Fig 3. CUSUM of Squares Text

Source: E-views 10.0 version data output

\section{Short Run OLS Relationship}

In estimating the short run nexus between digital banking and performance of commercial banks, the ARDL was applied and the result depicted in Tables 10. The outputs were interpreted using the coefficients of the individual variables, Adjusted R-square, $\mathrm{f}$ statistic and Durbin Watson.

Table 10. ARDL: Return on Asset and Digital Banking Instruments

\begin{tabular}{|c|c|c|c|c|}
\hline \multicolumn{3}{|c|}{ Dependent Variable: ROA } & & \\
\hline \multicolumn{2}{|l|}{ Method: ARDL } & & & \\
\hline \multicolumn{5}{|c|}{ Dynamic regressors (0 lag, automatic): POSG USSDG WEBG } \\
\hline \multicolumn{3}{|l|}{ Fixed regressors: $\mathrm{C}$} & & \\
\hline Variable & Coefficient & Std. Error & t-Statistic & Prob.* \\
\hline $\mathrm{ROA}(-1)$ & -0.084838 & 0.047169 & -1.798593 & 0.1465 \\
\hline POSG & -0.072258 & 0.011151 & -6.480029 & 0.0029 \\
\hline USSDG & 0.034380 & 0.006384 & 5.385177 & 0.0057 \\
\hline WEBG & 0.003652 & 0.003837 & 0.951811 & 0.3951 \\
\hline C & 4.838579 & 0.412989 & 11.71599 & 0.0003 \\
\hline R-squared & 0.956452 & \multicolumn{2}{|c|}{ Mean dependent var } & 2.232222 \\
\hline Adjusted R-squared & 0.912904 & \multicolumn{2}{|c|}{ S.D. dependent var } & 1.394729 \\
\hline S.E. of regression & 0.411614 & \multicolumn{2}{|c|}{ Akaike info criterion } & 1.362718 \\
\hline Sum squared resid & 0.677703 & \multicolumn{2}{|c|}{ Schwarz criterion } & 1.472287 \\
\hline Log likelihood & -1.132230 & \multicolumn{2}{|c|}{ Hannan-Quinn criter. } & 1.126268 \\
\hline F-statistic & 21.96309 & \multicolumn{2}{|c|}{ Durbin-Watson stat } & 1.225551 \\
\hline Prob(F-statistic) & 0.005524 & & & \\
\hline \multicolumn{5}{|c|}{ *Note: $p$-values and any subsequent tests do not account for model } \\
\hline \multicolumn{3}{|l|}{ selection. } & & \\
\hline
\end{tabular}

Source: Author's E-view 10.0 computations 


\section{Effects of Digital Banking on The Performance of Commercial Banks in Nigeria 2010 -2019}

\section{A Priori Expectation and Text of Probability}

The constant parameters for the study are positively related with return on assets. It has a positive coefficient of 4.838579 which implies that if all explanatory variables are held constant in the short-run, return on assets will increase by 4.838579 units. The probability value of 0.0003 which is less than $5 \%$ and the t-statistics value of 11.71599 which is greater than 2 shows that the constant is significant therefore if all the variables are held constant (C) has positive and significant effect on ROA.

Meanwhile the individual variables shows that POSG has significant effect on ROA while USSDG and WEBG has insignificant effect. The result indicates that in the short run digital banking has positive but insignificant effect on performance of commercial banks in Nigeria. The result is consistent with the study of (Oyewole et al ,2013; Abaenewe et al ,2013; Ogutu and Fatoki ,2019; Olaiya, and Adeleke ,2019; Ibrahim and Daniel,2019) which shows that digital banking has contributed positively to performance of commercial banks but has not significantly impacted the Banks when considering digital banking infrastructure and the number of population in the country. The coefficient of multiple determinants $\left(R^{2}\right)$ showed a coefficient of $0.956452 \approx 0.95$ which implies a $95 \%$ explanation of the behaviour of Return on assets by the totality of the explanatory variables: (POSG,USSDG and WEBG) on the short-run. The Adjusted $\mathrm{R}^{2}$ further prove this with the adjusted value of $0.912904 \approx$ 0.91 which implies that 91 percent explanation of the behaviour of return on assets by the totality of the explanatory variables with the remaining 9percent behaviour attributed to other variables outside the model otherwise referred to as the stochastic variables.

The F-statistic indicates that the model is well fit for the estimation because F-stat for the model is 21.96309 which is greater than F-critical value of 5.19 at 95 percent significance level. However, the Durbin Watson Statistic value of 1.225551 is symptomatic of auto correlation. Hence the autocorrelation text in table 8 which shows, there is no auto correlation problem in the model and could be used for statistical inference like hypothesis testing and forecasting.

\section{Granger Causality Test}

Table 11 shows that there exist unidirectional relationship between POSG and USSDG on ROA with causality flowing from ROA to POSG and USSDG. This goes to show that digital banking will allow banking customers to access banking service from anywhere which in turn improve the profitability of of commercial banks in the country.

Table 11. Pairwise granger causality test on input variables

\begin{tabular}{|l|l|l|l|}
\hline Null Hypothesis: & Obs & F-Statistic & Prob. \\
\hline POSG does not Granger Cause ROA & 8 & 0.08587 & 0.9199 \\
\hline \multicolumn{2}{|l|}{ ROA does not Granger Cause POSG } & 17.2103 & 0.0227 \\
\hline USSDG does not Granger Cause ROA & 8 & 0.01529 & 0.9849 \\
\hline \multicolumn{2}{|l|}{ ROA does not Granger Cause USSDG } & 16.5284 & 0.0240 \\
\hline WEBG does not Granger Cause ROA & 8 & 2.38789 & 0.2396 \\
\hline ROA does not Granger Cause WEBG & 4.87675 & 0.1141 \\
\hline
\end{tabular}

Source: Granger Causality test output data using e-views 10

\section{CONCLUSION AND POLICY IMPLICATION}

Technology Acceptance Theory states that perceived ease of use and usefulness of technological tool determines the extent of consumer acceptance. The idea is that for banks to drive profitability through digital banking, it must be accepted by the people and to be acceptable to the people, it should be perceived useful and also very easy to use. Despite the benefits of digital banking in Nigeria there are a lot of challenges facing the introduction of digital banking like the issue of poor network, security, frauds and cyber crimes.

Various studies on this topic have been undertaken by various researchers and their results are contradictory as such the study tends to fill the knowledge gap in literature by studying the effect of digital banking and performance of commercial banks in Nigeria from 2010 to 2019. Descriptive statistics was used to explain the characteristics of the data series, thereafter that the unit root status of the variables was established and was discovered to be intergrated at order I(0) and I(1). This necessitated the use of Autoregressive Distributed Lag in the study and the result indicates that digital banking has positive and insignificant effect on performance of commercial banks in Nigeria. The result is in line with the previous studies of (Oyewole et al ,2013; Abaenewe et al ,2013; Ogutu and Fatoki ,2019; Olaiya, and Adeleke ,2019; Ibrahim and Daniel,2019) . The study therefore agrees with Technology Acceptance Theory that for digital banking to affect performance of commercial banks it must be easy to use and acceptable to banks customers. Despite the importance of digital banking to the country and commercial banks ,there 


\section{Effects of Digital Banking on The Performance of Commercial Banks in Nigeria 2010 -2019}

seems to be a lot of challenges in order to make it easy and generally accepted in the country as such the study makes the following recommendations Provision of a relatively stable network: In other to reduce number of failed transactions, banks are hereby encouraged to liaise with network providers and their engineers to develop a standardized network platform exclusively for each of the digital banking channels. This will help reduce traffic on their network and improve efficiency. Ease of tracing of transactions can also be achieved. Dedication of helpdesk for resolving digital banking related issues only: With the increasing number of failed transactions leading to increasing customers' complaints, it is advised that each bank creates a separate desk for resolving digital banking related issues. This will lead to timely resolution of customer's complaints and also improve service delivery thereby ensuring overall customer satisfaction and loyalty. Digital banking education: Since digital banking has proven to be effective in driving income, all parties involved in digital banking (banks, telecom companies, cards companies, unified payments) should put resources together to drive digital banking education so as to get more people activated on digital banking channels. If the banking populace are well educated the are likely to embrace digital banking with all their heart (as opined by the technology acceptance theorists). Creation of Cyber Security Department: With advancement in technology and increasing number of people signing up for digital banking channels, it is recommended that all banks should have 24 hours working cyber security department. This department should be separated from the internal control department and should be manned by professionals in area of cyber security. This is to provide 24 hours surveillance, protect the bank from cyber attacks, and provide safety for users of digital banking (especially web banking) so as to sustain and improve on the existing performance on the channels and to ensure that the channels are not hijacked by cyber criminals.

\section{REFERENCES}

1) Abaenewe, C., Ogbulu, M., \& Ndugbu, O. (2013). Electronic banking and bank performance inNigeria. West African Journal of Industrial \& Academic Research, 6(1), 13-31.

2) Chebii, M. (2013). "Kenya commercial bank and SME banking alternative channels". Retrieved from http://smefinanceforum.org/post/kenya-commercial-bank-and sme-bankingalternative Channels- By milkahchebiifrom-kcb.

3) Crane, D. (2010). Electronic banking for the poor: Panacea, potential and pitfalls. Retrieved from http//www. Microsave.org.

4) David-West O., Olubanjo A., Olawale A., Aluko T., Iheanachor N., lyoha F., Kelikumel., Muritala O., Nwagwu I., Salami A., Taiwo, I., \& Umukoro, I. (2018). Digital financial services in Nigeria, State of the market report, sustainable and inclusive digital financial services. Lagos business school.

5) Davis, F., Bagozzi, R., \& Warshaw, P. (1989). User acceptance of computer technology: A comparison of two theoretical models. Management science, 35(8), 982-1003.

6) Eze, G., \& Egoro, S. (2016). Electronic Banking and Profitability of Commercial Banks in Nigeria. Journal of Finance and Economic Research 3(1),40-55.

7) Ginn, M. (2011). Role of Alternate Channels in Banking and Wealth Management. Retrieved from http://www.infosys.com/finacle/solutions/thoughtpapers/Documents/role-alternate channels.pdf.

8) Greenwood, J., \& Jovanovic, B. (1990). Financial development, growth, and the distribution of income. Journal of Political Economy, 98(5), $1076-1107$

9) Galor O., \& Zeira J. (2000). Income distribution and macroeconomics. Review of EconomicStudies 60(2), 35-52

10) Auwal M, Shafiu A and Haslinda H. (2015). The Impact of Online Banking on the Performance of Nigerian Banking Sector. International conference on E-commerce (ICOEC 2015), | Kuching Malaysia.

11) Ibrahim, A. \& Daniel, C. (2019). Impact of E-Banking on the Development of Banking Sector in Nigeria. International Journal of Managerial Studies and Research (IJMSR). 7, (2). PP 19-27.

12) IBM Global Services (2015). The new heights in technology for business and organisations. London UK. McHills books. Outlook 25.

13) Isibor, A., Omankhanlen, E., Okoye, L., Achugamonu, B., Adebayo, M., Afolabi, G., and Ayodeji, O. (2018) Impact of Electronic Banking Technology on Customers' Satisfaction and Economic Growth in Nigeria, International Journal of Civil Engineering and Technology, 9(12), pp. 536-544

14) Ivatury, G., \& Lyman, T. (2016). Use of agents in branchless banking for the Poor: Rewards, Risks, and Regulation. Washington D.C: CGAP Focus 38

15) Juddy, M. (2013). The effect of electronic banking on financial performance of commercial banks in Kenya. A research project submitted in partial fulfillment of the requirements of the master of business administration degree, university of Nairiobi. 


\section{Effects of Digital Banking on The Performance of Commercial Banks in Nigeria 2010 -2019}

16) Jensen, M., \& Meckling, W. (1976). Theory of the firm: managerial behavior, agency costs, and ownership structure. Journal of Finance and Economics, 3(30),45-60.

17) Kairiza, C., Kiproro, A. \& Magadzire, G. (2017). Assessment of Factors Influencing Adoption of Agency Banking in Kenya: The Case of Kajiado North Sub County. International Journal of Business and Commerce, 3(8), 91-111.

18) King, T., Nuxoll, D., \& Yeager, T. (2006). Are the Causes of Bank Distress Changing? Can Researchers Keep Up? Federal Reserve Bank of St. Louis Review, 88(2), 57-80.

19) Kongiri, A. (2012). Effects of CAMEL variables on bank efficiency: A panel analysis of Kenya Commercial Banks. Unpublished MBA Research project. University of Nairobi.Laukkanen \& Lauronen, (2005). How distribution is transforming retail banking: Changesleading banks are making. Journal of Retail Banking Services, 17(3), 1-9.

20) Liu, C., \& Arnett, K. (2000). Exploring the factors associated with Web site success in the context of electronic Commerce. Information \& management Journal, 38(1), 23-33.

21) Malhotra, T., \& Singh, O. (2009). The impact of e-banking on the profitability of banks: A study of Indian banks.Journal of Public Administration and Governance, 1(1), 31-38.

22) Melzer, A. (2006). Alternate banking channels for customer convenience. International Journal of Scientific Research, 2(2), $2277-8179$.

23) Monyoncho, L. (2015). Relationship between banking technologies and financial performance of commercial banks in Kenya. International Journal of Economics, Commerce and Management United Kingdom 3(11).

24) Ndungu, C. (2015). The effect of alternative banking channels on financial performance of commercial banks in Kenya. A research project submitted in partial fulfillment of the requirements for the award of the master of business administration degree of the University of Nairobi.

25) Nigerian Inter-bank Settlement system, (2018). POS adoption and Usage. A study on Lagos State.

26) Ogilvie, B. (2008). Overview of electronic banking in Nigeria. International Journal of Multidisciplinary Research Development. 2 (7), 336 -342.

27) Ogutu, M., \& Fatoki, O. (2019). Effect of e-banking on financial performance of listed commercial banks in kenya. Global scientific Journals, 7(9), 2320-9186.

28) Okiro, K., \& Ndungu, J. (2013). The impact of mobile banking and internet banking onperformance of financial institutions. European Scientific Journal, 9(13), 146-161.

29) Olaiya, A.and Adeleke, K.(2019). Electronic banking and profitability of deposit money banks in Nigeria.Journal of association of professional bankers in education.5,(1),75-86.

30) Onay, W. (2008). Electronic banking products and performance of Turkish listed deposit moneybanks. American Journal of Computer Technology and Application, 1(10),138-148.

31) Oyewole S., Abba M., Gambo J. \& Abam A. (2013). E-banking and bank performance: evidence from Nigeria. International Journal of Scientific Engineering and Technology. 2(1)8, 766-771

32) Oyewole, O., \& El-maude, G. (2013). E-banking and performance of commercial banks in Nigeria.Journal of Retail Banking Services, 23(5), 43-71.

33) Rosen T. (2013). The effect of the use of mobile banking and agent banking in the banking system in Kenya. Banking and finance Law Review. 31(2), 389-401.

34) Ukoh, N. (2019). Digital Finance: key to achieving financial inclusion in microfinance banks.Paper presented to Board \& mgt staff of Nwannegadi mfb Itd at catholic pastoral centre, orlu, imo-state.

35) Scott, N., \& Davis, F. (2015). Financial inclusion through mobile banking: A Case of Bangladesh. Journal of Applied Finance \& Banking, 4(6), 109-136

36) Sousa, R., \& Voss, C. (2006). Service quality in multi-channel services employing virtual channels, Journal of Service Research, 8 (4), 356 - 371.

37) Scholtens, M., \& Van W. (2003). The relationship between commercial bank profit rates and banking Concentration in Canada, Western Europe and Japan. Journal of Banking \& Finance, 3, 209-219

38) Taiwo, J., \& Agwu, M. (2017). The role of e-banking on operational efficiency of banks in Nigeria. Basic Research Journal of Business Management and Account. 6(1) 01-10. Available online http//www.basicresearchjournals.org

39) Venkatesh, K. (2003). Unified theory of acceptance and use of technology. Washington, DC:Brookings Institution.

40) Yorulmaz, R. (2018). An analysis of the construction of global digital banking indices. Borsa Istanbul Review. 3 (18) $24-$ 38. 